\title{
Blood Heavy Metal Levels in Children with Autism Spectrum Disorder: A Cross- Sectional Study From Northern India
}

\section{Rachna Sehgal ${ }^{1}$, Sheffali Gulati ${ }^{2}$, Yogendra Kumar Gupta $^{3}$, Savita Sapra ${ }^{4}$, Manju Mehta $^{5}$, Ravindra Mohan Pandey ${ }^{6}$, Gajendra Kumar ${ }^{3}$, Amita Srivastava ${ }^{3}$ and Madhulika Kabra ${ }^{7}$}

\author{
${ }^{1}$ Department of Paediatrics, Vardhman Mahavir Medical College and Safdarjung Hospital, India \\ ${ }^{2}$ Child Neurology Division, Department of Paediatrics, All India institute of Medical Sciences, New Delhi, India \\ ${ }^{3}$ Department of Pharmacology, All India institute of Medical Sciences, New Delhi, India \\ ${ }^{4}$ Department of Paediatrics, All India institute of Medical Sciences, New Delhi, India \\ ${ }^{5}$ Department of Psychiatry, All India institute of Medical Sciences, New Delhi, India \\ ${ }^{6}$ Department of Biostatistics, All India institute of Medical Sciences, New Delhi, India \\ ${ }^{7}$ Genetics Unit, Department of Paediatrics, All India institute of Medical Sciences, New Delhi, India
}

\section{Correspondence: \\ Dr Sheffali Gulati \\ Chief Child Neurology Division, \\ Department of paediatrics, \\ All India Institute of Medical sciences, \\ New Delhi, India. \\ Email: sheffaligulati@gmail.com}

DOI: $10.3126 /$ jnps.v39i1.19905

Submitted on: $2020-01-02$

Accepted on: 2020-02-08

Acknowledgements: None

Funding: Nil

Conflict of Interest: None declared

Permission form IRB: Yes

To cite this article: Sehgal R, Gulatli S, Gupta YK, Sapra S, Mehta M, Pandey RM, Kumar G, Srivastava A and Kabra M. Blood heavy metal levels in children with Autism Spectrum Disorder : A crosssectional study from Northern India. J Nepal Paediatr Soc. 2019;39(1):6-14.

\section{ABSTRACT}

Introduction: The role of heavy metals in the etio-pathogenesis of ASD is controversial. Paucity of studies from Indian subcontinent with different sociocultural and environmental background prompted the present study.

Methods: Sixty children aged three to 12 years with Autism Spectrum Disorder (ASD) and 60 age matched controls were enrolled. Detailed history including possible exposure history to various heavy metals was taken. Severity of ASD was assessed using Childhood Autism Rating Scale 2. Blood level of metals was estimated by Inductively coupled plasma - atomic emission spectroscopy (ICP-AES).

Results: Mean blood mercury levels in the two groups of ASD and controls was comparable $(\mathrm{p}=0.28)$. Median blood cadmium and arsenic levels were higher in controls possibly due to higher ground water use and insecticide exposure. $(7 / 60$ versus $17 / 60, p=0.04)$ and $(2 / 60$ versus $7 / 60, p=0.08)$ while mean blood zinc level was lower in controls. Lead was significantly higher in greater proportion of children with ASD. $(11 / 60$ vs $1 / 60, p=0.002)$. Children with ASD had significantly higher pica $(26 / 60$ versus $10 / 60, p=0.001)$ and higher median number of days of antibiotics during infancy (24.5 $(0-120)$ versus $15(0-60), p=0.004)$. None of the heavy metal tested had significant correlation with the severity of ASD.

Conclusions: Mean blood mercury, lead, zinc, arsenic and cadmium did not show significant association with diagnosis of ASD. High levels of toxic metals in both children with ASD and controls points towards an urgent need to contain environmental pollution by heavy metals.

Key words: ASD; heavy metals; ICP-AES; lead; mercury

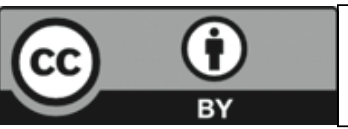

This work is licensed under creative common attribution 3.0 license 


\section{INTRODUCTION}

Autism Spectrum Disorder (ASD) is a neurobehavioral disorder believed to occur when environmental influences act in concert with or independently of heritable factors. Amongst the environmental factors, the role of heavy metals in causation seems intuitive. There is a biologic plausibility of disruption of enzyme systems by heavy metals, therapeutic proposal of possible benefit of chelation therapy and environmental ubiquity of various heavy metals.

Previous investigations have compared measurements of heavy metals in blood ${ }^{1}$, hair ${ }^{2}$, teeth $^{3}$, urine ${ }^{4}$ in children with and without ASD. However, there are discordant results of association, especially of mercury with autism. Further, neither the role of metals like arsenic, cadmium and zinc; nor the differential association of heavy metals with ASD severity have been adequately examined. Moreover, these studies are from different geographical localities with different dietary, cultural and socioeconomic realities. There are also concerns about laboratory quality control and assurance.

Thus, the association between heavy metals and ASD needs further studies, using standardised methods to clarify the dilemma of etiopathogenesis, as the exposure is potentially preventable by environmental modification or treatment. ${ }^{5}$ Therefore, the present study has been formulated to address this knowledge gap.

\section{METHODS}

This case control study was done at a tertiary care research, training and referral institute in Northern India. The participants were enrolled after obtaining Institutional Ethics Committee clearance and written informed consent. The flow of patients in the study is depicted in figure 1 .

The study subjects fulfilled all the following inclusion criteria: Group A ( $\mathrm{N}=60)$ : ASD: 3-12year-old consecutive children who met DSM 5 criteria for ASD. Group B $(\mathrm{N}=60)$ : Controls; 3-12-year-old children with age appropriate development (DQ > 84) without features of ASD. They were enrolled from the children attending the blood collection centre attached to Paediatrics ward for investigation of fever $(n=43)$, or those attending Paediatrics OPD for investigation of nonneurological co-morbidities [Constipation / poor growth: $(\mathrm{n}=10)$; Recurrent diarrhoea $(\mathrm{n}=7)$. Healthy controls were not chosen in view of ethical concern of drawing blood sample.

Children were excluded from Group A if they had received any chelating drug in the past or had evidence of chronic systemic illness: like chronic renal disease, cardiac disease or hepatic disease; or from Group B if they had either presence of ASD (meeting DSM 5 criteria) or had received any chelating drug or had a chronic systemic illness. DSM 5 criteria $(2013)^{6}$ were used to make a diagnosis of ASD. Severity of ASD was assessed using Childhood Autism Rating Scale (CARS), $2^{\text {nd }}$ edition (2010). ${ }^{7}$

In the group of controls, the intelligence of the children was measured by the cognitive sub test of the Developmental Profile 3 that was used to calculate the equivalent DQ standard score as per the guidelines. Detailed perinatal, past, developmental and possible exposure history to various heavy metals was also taken from parents of each child.

Exposure history was taken to find out the environmental factors that may have contributed to elevated levels of heavy metals in blood of subjects, if any. The maximum cumulative thiomersal that contains mercury and is found as a preservative in few vaccines, was calculated from the immunisation history and using the values previously assessed. ${ }^{8}$ Average antibiotic usage in infancy was calculated by multiplying average number of episodes of illness with the average number of days of antibiotic days for each child. This was done as higher oral antibiotic use is proposed to almost completely inhibit excretion of mercury due to alteration of gut flora. ${ }^{3}$ The presence of power plants, small scale industries using coal, battery manufacturing plants, cement industry that may contribute to presence of cadmium, lead pollution were considered significant if they were within $1 \mathrm{~km}$ of residence. History of use of enamel paint at home (source of lead) in last one year, use of maternal dental 


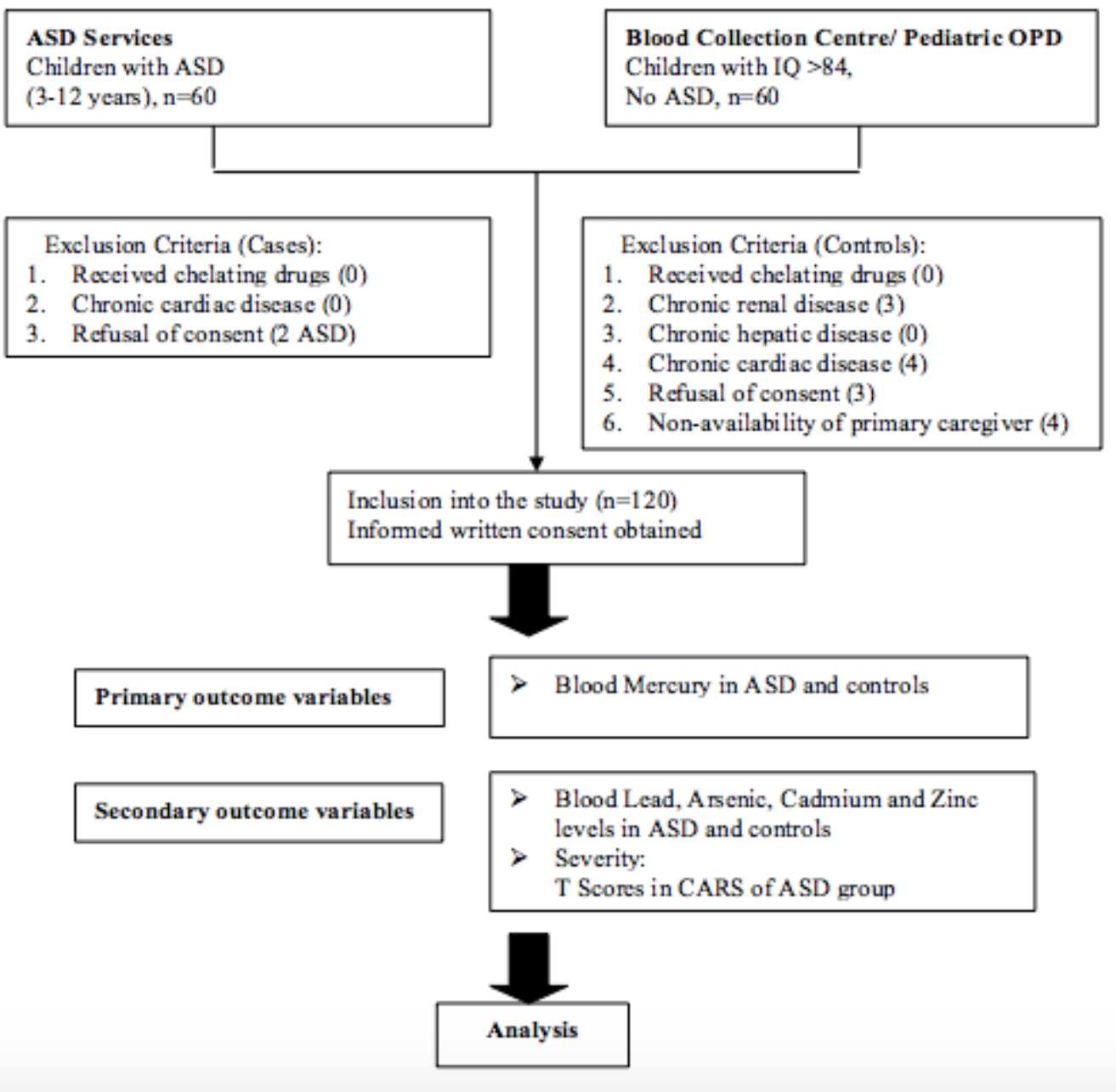

Figure 1. Study flow diagram

amalgams containing mercury before or during pregnancy, presence of dental amalgams in the child, average (median number) of fish servings (believed to concentrate heavy metals) per month were assessed. Other possible sources of lead, cadmium, zinc and arsenic included use of surma, pica, ground water, traditional medicines were also taken. Insecticide exposure was considered if child resided in a rural locality with frequent visits to the farm.

Whole blood venous samples, $1 \mathrm{ml}$ from each participant were collected in commercially available heparinised polypropylene tubes for Blood Lead $(\mathrm{Pb})$, Mercury $(\mathrm{Hg})$, Zinc( $\mathrm{Zn})$, Cadmium (Cd), Arsenic (As) estimation with ICPAES (Induction coupled plasma Atomic emission spectrophotometer). Samples were promptly labeled and stored at $-80 \cdot \mathrm{C}$ till digestion. Each sample was assigned a code before sample preparation. Closed-multimode-microwave was used for complete digestion of blood samples using $70 \%$ Nitric acid as a digestion reagent. The Limit of Detection (LOD) was determined based on three times of standard deviation running a matrix blank.

ICP-AES, fitted with a cross flow nebuliser and a quartz spray chamber was used with the conditions: forward power of $1.0 \mathrm{~kW}$; vacuum pressure of $1.8 \times 10-6$; nebuliser flow rate of $0.84 \mathrm{~L} / \mathrm{min}$; dual detector and sweep/reading of 3 , reading/replicate of 3, dwell time of $5 \mathrm{sec}$ and integration time of 10 sec. The precision was established by triplicate runs involving different operators for the same batch of samples.

Blood Mercury level in children with ASD and controls was taken as primary outcome variable as mercury has most often been incriminated as a 
neurotoxicant. A previous case-control study ${ }^{9}$ that compared the hair and blood mercury levels of children with autistic spectrum disorder with a control group of normal children found difference in mean blood mercury between children with ASD and control to be $4.85 \mathrm{nmol} / \mathrm{L}$ with standard deviation of 15.65 and an effect size of 0.3 . Considering 2-sided alpha- 0.05, 80\% Power, sample is 176 in each group. Sample taken due to feasibility purposes was 60 children with ASD and 60 controls.

The secondary outcome variables included blood Lead, Arsenic, Cadmium and Zinc levels in ASD and controls; and severity of ASD as judged by T Scores in CARS 2 of ASD group. For descriptive purpose: $\mathrm{T}$ score $\leq 39$ was as low level of autism related behaviour, 40 to 54 was taken as average level and $\geq 55$ was taken as high level.

\section{RESULTS}

The demographic characteristics of participants are given in Table 1. Antenatal risk factors were present in $17 / 60$ children $(28.3 \%)$, perinatal asphyxia in $8 / 60(13.3 \%)$ and neonatal jaundice in 4/60 (6.7\%) children with ASD. The co morbidities included epilepsy in 20/60 (33.3\%), sleep problems $12 / 60(20 \%)$ and dysmorphism 8/60 (13.3\%). The types of seizure seen were GTCS (10), infantile spasms (4), complex partial seizures (2) and absence seizures (4).
Table 1. Characteristics of children in the study (Group A v/s B)

\begin{tabular}{|c|c|c|c|}
\hline S. N. & Characteristic & $\begin{array}{r}\text { ASD } \\
\text { (Group A) } \\
\mathbf{N}=60\end{array}$ & $\begin{array}{r}\text { Controls } \\
\text { (Group B) } \\
\mathbf{N}=60\end{array}$ \\
\hline 1 & $\begin{array}{l}\text { Age, } \\
\text { Mean } \pm \mathrm{SD} \\
(95 \% \mathrm{CI}) \\
\begin{array}{l}\text { Median } \\
\text { (range) }\end{array}\end{array}$ & $\begin{array}{l}65.9 \pm 29.0 \\
(58.4-73.4) \\
56 \\
(36-144)\end{array}$ & $\begin{array}{l}75.4 \pm 30 \\
(67.7-83.2) \\
72.5 \\
(36-144)\end{array}$ \\
\hline 2 & Male : Female & $42: 18$ & $38: 22$ \\
\hline 3 & $\begin{array}{l}\text { Severity score } \\
\text { Mean } \pm \text { SD } \\
(95 \% \text { C.I. })\end{array}$ & $\begin{array}{l}\text { CARS2-ST: } \\
\text { T Score } \\
57.0 \pm 7.7 \\
(55.0-59.0)\end{array}$ & - \\
\hline
\end{tabular}

Age is described in months; CARS2-ST -Childhood ASD Rating Scale, $2^{\text {nd }}$ Edition-Standard Version; SD - standard deviation; $C I$ - confidence interval

Almost half of children with ASD, 27/60 (45\%), were treatment naïve. Majority of children with ASD were on antiepileptic drugs and behavioural therapy. No child was on any chelators, haematinic or zinc supplementations in either groups. Geometric mean and median blood mercury levels in the two groups were comparable. The comparative geometric mean and median blood levels of cadmium, arsenic, lead and zinc are depicted in Table 2.

Table 2. Comparison of blood heavy metal analysis in children with ASD and controls

\begin{tabular}{|c|c|c|c|c|c|}
\hline SN & & Heavy Metal & $\operatorname{ASD}(n=60)$ & Control $(n=60)$ & p value \\
\hline \multirow[t]{2}{*}{1} & \multirow{2}{*}{$\begin{array}{l}\text { Blood Mercury } \\
\text { (ppb) }\end{array}$} & Geometric mean (95\% C.I.) & $6.2(5.6-6.9)$ & $7.4(5.6-9.9)$ & \multirow[t]{2}{*}{0.28} \\
\hline & & Median (range) & $5.9(25-47)$ & $6.5(0.5-223.1)$ & \\
\hline \multirow[t]{2}{*}{2} & \multirow{2}{*}{$\begin{array}{l}\text { Blood } \\
\text { Cadmium (ppb) }\end{array}$} & Geometric Mean (95\% C.I.) & $2.8(1.9-4.1)$ & $7.6(5.3-10.9)$ & \multirow[t]{2}{*}{$0.001 *$} \\
\hline & & Median (range) & $1.2(0-21.6)$ & $17.8(0-26.5)$ & \\
\hline \multirow[t]{2}{*}{3.} & \multirow{2}{*}{$\begin{array}{l}\text { Blood Lead } \\
\text { (ppb) }\end{array}$} & Geometric Mean (95\% C.I.) & $61.00(52.1-71.4)$ & $59.9(55.6-64.6)$ & \multirow[t]{2}{*}{0.57} \\
\hline & & Median (range) & $60.8(0-172.4)$ & $57.4(22.3-229.1)$ & \\
\hline \multirow[t]{2}{*}{4} & \multirow{2}{*}{$\begin{array}{l}\text { Blood Zinc } \\
\text { (ppb) }\end{array}$} & Geometric Mean (95\% C.I.) & $1044.71(919.50-1186.99)$ & $906.7(811.0-1013.7)$ & \multirow[t]{2}{*}{$0.02 *$} \\
\hline & & Median (range) & $1000.7(274.7-6471.7)$ & $802.3(453.6-4409.4)$ & \\
\hline \multirow[t]{2}{*}{5.} & \multirow{2}{*}{$\begin{array}{l}\text { Blood Arsenic } \\
\text { (ppb) }\end{array}$} & Geometric Mean (95\% C.I.) & $0.3(0.2-0.4)$ & $0.9(0.6-1.4)$ & \multirow[t]{2}{*}{$0.01^{*}$} \\
\hline & & Median (range) & $0.3(0-5.1)$ & $0.7(0-5.9)$ & \\
\hline
\end{tabular}


Table 3. Comparison of blood mercury levels in different studies

\begin{tabular}{|c|c|c|c|c|c|}
\hline \multirow[t]{2}{*}{ Parameters } & \multicolumn{2}{|c|}{ Present study } & EPA population average & \multicolumn{2}{|c|}{ Ip et al. } \\
\hline & Cases & Controls & & Cases & Controls \\
\hline Age & \multicolumn{2}{|l|}{3 - 12 years } & $<11$ years & \multicolumn{2}{|c|}{$4-11$ years } \\
\hline \multicolumn{6}{|c|}{ Blood Hg (ppb) } \\
\hline A.M. & $7.1 \pm 6.6$ & $15.6 \pm 24.6$ & Not specified & 3.9 & 3.9 \\
\hline G.M. & 6.2 & 7.4 & $0.3-0.1$ & \multicolumn{2}{|c|}{ Not specified } \\
\hline
\end{tabular}

A.M. - arithmetic mean; G.M. - geometric mean; ppb - parts per billion

In the present study, the blood mercury in ASD population is lower than the controls, still it is more than the population averages of other nations as reported by Environmental Protection Agency (EPA), USA and previous studies (Table 3). ${ }^{9}$ None of the heavy metal tested had significant correlation with the severity of ASD. (Table 4). However, there was a trend of elevated blood level of all heavy metals tested as well as presence of zinc deficiency in greater proportion of children with severe ASD (Table 5).

Pica was significantly more prevalent in children with ASD as compared to controls (26/60 versus $10 / 60, p=0.001)$. Children with ASD also received significantly higher median number of days of antibiotics during infancy $(24.5,0-120)$ versus 15 $(0-60, p=0.004)$. However, ground water use and insecticide exposure were higher in controls $(7 / 60$ versus $17 / 60, p=0.04)$ and $(2 / 60$ versus $7 / 60$, $\mathrm{p}=0.08)$ respectively. Other variables were not significant. Lead was significantly higher in greater proportion of children with ASD. Other heavy metals are shown in Table 6.

Table 4. Correlation of severity score (T score) of ASD with blood heavy metal levels

\begin{tabular}{|r|l|l|}
\hline S.No. & $\begin{array}{l}\text { Blood heavy metal } \\
\text { (ppb) }\end{array}$ & $\begin{array}{l}\text { Spearman's Rho } \\
\text { (p value) }\end{array}$ \\
\hline $\mathbf{1}$ & Blood Lead & $0.1(0.47)$ \\
\hline $\mathbf{2}$ & Blood Cadmium & $0.2(0.20)$ \\
\hline $\mathbf{3}$ & Blood Zinc & $0.2(0.15)$ \\
\hline $\mathbf{4}$ & Blood Arsenic & $0.3(0.05)$ \\
\hline $\mathbf{5}$ & Blood Mercury & $0.2(0.25)$ \\
\hline
\end{tabular}

\section{DISCUSSION}

The preponderance of males in the present study is comparable to $2.1: 1$ found in a previous study. ${ }^{10}$ Other authors have reported relatively higher male preponderance of $3-4: 1 .^{11}$

The presence of other antenatal $(28.3 \%)$ and perinatal risk factors $(13.3 \%)$ is also in accordance with the theory of causation implicating pre- and perinatal brain injury as one of the risk factors for autism. ${ }^{12}$ The prevalence of epilepsy (33.3\%) in the case cohort is also comparable to $31.3 \%$ observed

Table 5. Frequency of elevated/ deficient heavy metals in different subgroups of ASD

\begin{tabular}{|c|c|c|c|c|c|}
\hline \multirow[t]{2}{*}{ SN } & \multirow{2}{*}{$\begin{array}{l}\text { Heavy } \\
\text { metal }\end{array}$} & \multicolumn{3}{|c|}{ ASD subgroups } & \multirow{2}{*}{$\begin{array}{l}\text { p } \\
\text { value }\end{array}$} \\
\hline & & $\begin{array}{l}\text { Low } \\
(n=3)\end{array}$ & $\begin{array}{l}\text { Average } \\
(n=14)\end{array}$ & $\begin{array}{l}\text { Severe } \\
(n=43)\end{array}$ & \\
\hline 1 & $\begin{array}{l}\text { Elevated } \\
\text { Cadmium } \\
(>10 \mathrm{ppb})\end{array}$ & 0 & 3 & $\begin{array}{l}5 \\
(11.6)\end{array}$ & 0.61 \\
\hline 2 & $\begin{array}{l}\text { Elevated } \\
\text { Lead } \\
(>100 \mathrm{ppb})\end{array}$ & 2 & 1 & $\begin{array}{l}8 \\
(18.6)\end{array}$ & 0.10 \\
\hline 3 & $\begin{array}{l}\text { Elevated } \\
\text { Zinc } \\
(>1300 \mathrm{ppb})\end{array}$ & 0 & 2 & $\begin{array}{l}12 \\
(27.9)\end{array}$ & 0.41 \\
\hline 4 & $\begin{array}{l}\text { Elevated } \\
\text { Mercury } \\
(>10 \text { ppb) }\end{array}$ & 0 & 0 & $2(4.7)$ & 0.66 \\
\hline 5 & $\begin{array}{l}\text { Elevated } \\
\text { Arsenic } \\
(>5 \mathrm{ppb})\end{array}$ & 0 & 0 & $1(2.3)$ & 0.81 \\
\hline 6 & $\begin{array}{l}\text { Deficient } \\
\text { Zinc } \\
(<1000 \mathrm{ppb})\end{array}$ & 3 & 6 & $\begin{array}{l}24 \\
(55.8)\end{array}$ & 0.46 \\
\hline
\end{tabular}


Table 6. Comparison of frequency of elevated/ deficient heavy metals in children with ASD and controls

\begin{tabular}{|c|c|c|c|c|}
\hline SN & Heavy metals & $\begin{array}{l}\text { ASD } \\
(N=60) \\
n(\%)\end{array}$ & $\begin{array}{l}\text { Control } \\
(\mathrm{N}=60) \\
n(\%)\end{array}$ & p value \\
\hline 1 & $\begin{array}{l}\text { Elevated } \\
\text { Cadmium } \\
(>10 \text { ppb) }\end{array}$ & $8(13.3)$ & $37(60.7)$ & $0.001 \#$ \\
\hline 2 & $\begin{array}{l}\text { Elevated Lead } \\
(>100 \mathrm{ppb})\end{array}$ & $\begin{array}{l}11 \\
(18.3)\end{array}$ & $1(1.6)$ & $0.002 *$ \\
\hline 3 & $\begin{array}{l}\text { Elevated Zinc } \\
(>1300 \mathrm{ppb}) \\
\text { Deficient Zinc } \\
(<1000 \mathrm{ppb}) \\
\text { Normal zinc } \\
(1001-1300)\end{array}$ & $\begin{array}{l}14 \\
(23.3) \\
30 \\
(50) \\
16 \\
(26.7)\end{array}$ & $\begin{array}{l}13 \\
(21.3) \\
41 \\
(67.2) \\
6 \\
(10)\end{array}$ & $\begin{array}{l}0.14 \\
0.01 *\end{array}$ \\
\hline 4 & $\begin{array}{l}\text { Elevated } \\
\text { Arsenic } \\
(>5 \mathrm{ppb})\end{array}$ & $1(1.7)$ & $14(23.0)$ & $0.001 \#$ \\
\hline 5 & $\begin{array}{l}\text { Elevated } \\
\text { Mercury } \\
(>10 \text { ppb })\end{array}$ & $2(3.3)$ & $12(19.7)$ & $0.005^{*}$ \\
\hline
\end{tabular}

earlier ${ }^{11}$. There was no patient with myoclonic seizures unlike Juneja et al. but in line with observation of other investigators. ${ }^{13}$ Pica was found in $26(43.3 \%)$ patients which is almost double of $21.5 \%$ in other study. ${ }^{11}$ The children used to lick walls, floor, eat paper, threads, dust, rubber, etc. Although the association of pica and ASD was found to be highly significant, whether it was the cause or effect of underlying illness is not clear.

The median blood mercury levels in group A (ASD) and group B (control) were found to be comparable. While few previous authors ${ }^{9,14}$ proposed a possible association between blood mercury level and ASD, others found no such association. $^{1}$

In addition, few studies have attributed reduced levels of mercury in hair, teeth and urine in subjects with ASD to be due to decreased excretory or detoxifying capacity of individuals. ${ }^{2,4,15}$ The present study was a preliminary study to find possible association of blood mercury with exposure through several sources as our dietary, socio- cultural and environmental influences are markedly different from the western and east Asian population where earlier studies have been conducted.

Moreover, the controls in the present study were not healthy population control like school going healthy children due to ethical concerns. Thus, a larger sample size study, possibly multicentric study with simultaneous exposure and excretion capacity as evidenced by blood and hair levels in comparison with healthy controls may yield a more meaningful conclusion.

Mercury, cadmium, arsenic and lead have no biological value. Thus the ideal blood levels of these metals is zero ppb. ${ }^{16}$ However, due to their consistent exposure in the environment, blood levels of these metals tend to increase.

Cadmium is a toxic metal whose intoxication is usually the result of smoking, unintentionally discarded batteries, water, food and air contamination. ${ }^{17}$ The association of cadmium with ASD has been controversial. While hair cadmium was found to be significantly increased in children with ASD in a study from Georgia, ${ }^{2}$ other investigators have reported decreased blood cadmium levels in children with pervasive development disorders. ${ }^{18,19}$ The determinants of lower blood levels of cadmium and arsenic in blood in the present study in children with ASD compared with controls are unclear. One of the possible explanations could be that the children with ASD are mostly reared indoor and seldom come in contact with outdoor environment and so are devoid of exposure to outdoor contamination by heavy metals. Secondly, the ground water use was also significantly higher in control population compared to controls. Both cadmium and arsenic are known to reach out into the ground water sources especially in Ganges belt. ${ }^{20}$ Many of the controls were from this geographical region.

In fact, another study has reported a correlation between clinically observable symptoms, blood and urine arsenic level and arsenic intake through water in a family from Central East India. ${ }^{20}$ Whether actually ground water was the source needs 
environmental studies so that appropriate preventive measures may be taken.

However mean blood lead levels were higher in children with ASD compared to controls in the present study, although this was not statistically significant. This may be because of more prevalent mouthing behaviour or pica in children with ASD. (Table 2). The normal hand to mouth activity of young children is known to effectively transfer lead laden dust from the environment into the body. ${ }^{21}$

India, particularly urban India with ongoing construction activities and unregulated industry, is battling with the problem of dust and its accompanying heavy metal especially lead pollution. ${ }^{22}$

Moreover, in another study, lead levels in enamel paints intended for residential use exceeded regulatory level of $<600 \mathrm{ppm}$, reaching up to 140,000 ppm. ${ }^{23}$ This is of grave concern and there is a need to take cognizance of the threat by both health care providers and public health officials.

Zinc deficiency was found in $50 \%$ children with ASD as compared to $67.2 \%$ controls in the present study. This highlights poor nutritional status regarding minerals prevalent in India. Tabatadze $T$ et al have also found association of lower hair zinc level with the diagnosis of ASD. ${ }^{2}$ This may in fact be related to poor intake of zinc rich foods as well as phytate rich local diet that interferes with zinc absorption. $^{24}$

In a previous study, hair levels of toxic elements; lead and mercury, were found to be well correlated with severity of ASD. ${ }^{25,26}$ Similar trend was seen in the present study with elevated levels of all five heavy metals seen amongst severe compared to low or average functioning ASD. (Table 4,5). A larger sample study might decipher if the correlation is statistically significant, if any.
To the authors' best knowledge, it is the first study of its kind from India. It yields useful information for healthcare programs and points towards an urgent need to contain environmental pollution by heavy metals.

Methodologically, confirmation of diagnosis in valid age ranges was done using standard validated diagnostic and statistical manual 5 (DSM-5) tool and collection of detailed data on multiple dietary terms and possible sources of heavy metals. Blood levels of heavy metals were estimated by ICP-AES which is fast and effective.

The possible role of pre-natal or early life mercury exposure in ASD will require analysis of maternal and population-based samples that predate the diagnosis. The addition of samples from hair, teeth may also give insight into cumulative exposure and excretory dysfunction. Exposure to environmental heavy metals from house dust, air pollution could not be accounted for and exposure history may be subject to recall bias.

\section{CONCLUSIONS}

Mean blood mercury, lead, zinc, arsenic and cadmium did not show significant association with diagnosis of ASD. However, lead was significantly higher in greater proportion of children with ASD. There was significant association of ASD diagnosis with pica and higher median number of days of antibiotics during infancy. Moreover, median blood cadmium and arsenic levels were significantly higher in controls possibly due to higher ground water use and insecticide exposure respectively. The blood mercury in the present cohort is more than the population averages of other nations. Zinc deficiency is highly prevalent in both ASD and controls.

\section{REFERENCES}

1. Hertz-Picciotto I, Green PG, Delwiche L, Hansen R, Walker C, Pessah IN. Blood mercury concentrations in CHARGE Study children with and without autism. Environ Health Perspect. 2010;118:161-6. DOI: 10.1289/ehp. 0900736. 
2. Tabatadze T, Zhorzholiani L, Kherkheulidze M, Kandelaki E, Ivanashvili T. Hair Heavy metal and essential trace element concentration in children with Autism Spectrum Disorder. Georgian Med News. 2015;248:77-82. PMID: 26656556.

3. Adams JB, Romdalvik J, Ramanujam VM, Legator MS. Mercury, lead, and zinc in baby teeth of children with autism versus controls. J Toxicol Environ Health. 2007;70:1046-51. DOI:10.1080/15287390601172080

4. Yorbik O, Kurt I, Haşimi A, Oztürk O. Chromium, cadmium, and lead levels in urine of children with autism and typically developing controls. Biol Trace Elem Res. 2010;135:10-5. DOI: 10.1007/s12011-009-8494-7.

5. Yassa HA. Autism: a form of lead and mercury toxicity. Environ Toxicol Pharmacol. 2014;38:1016-24. DOI: 10.1016/j.etap.2014.10.005.

6. American Psychiatric Association. Diagnostic and Stastical Manual of Mental Disorders. 5 ${ }^{\text {th }}$ Edn. (DSM 5), Washington DC: American Psychiatric Association; 2013.

7. Schopler E, Van Bourgondien ME, Wellman GJ. Childhood autism rating scale. $2^{\text {nd }}$ Edn (CARS2), LA. Western psychological press; 2010.

8. Ball LK, Ball R, Pratt RD. An assessment of thimerosal use in childhood vaccines. Paediatrics. 2001;107:1147-54. DOI:10.1542/peds.107.5.1147.

9. Ip P, Wong V, Ho M, Wong W. Mercury exposure in children with autistic spectrum disorder: case-control study. J Child Neurol 2004;19:431-4. Erratum in: J Child Neurol. 2007;22:1324. DOI:10.1177/088307380401900606

10. Juneja M, Mukherjee SB, Sharma S. A descriptive hospital based study of children with autism. Indian Paediatr. 2005;42:453-8. PMID: 15923691.

11. Dalton R, Forman MA, Boris NW. Pervasive developmental disorders and childhood psychosis. In: Behrman RE, Kleigman RM, Jensen HB, editors. Nelson Textbook of Paediatrics, $17^{\text {th }}$ ed. Philadelphia:WB Saunders. 2003;93-5.

12. Hirtz DG, Wegner A, Filipek PA. Autistic spectrum disorders. In: Swaiiman KS, Ashwal S, Ferriero DM, editors. Paediatric Neurology: Principles and Practice, $4^{\text {th }}$ ed. Philadelphia: Mosby Inc; 2006, p 905-35.

13. Volkmar FR, Nelson K. Seizure disorder in autism. J Am Acad Adolesc Psychiatry. 2004;45:135.

14. Geier DA, Audhya T, Kern JK, Geier MR. Blood mercury in autism spectrum disorders: is there a threshold level. Acta Neurobiol exp. 2010;70:177-86. PMID: 20628441.

15. Fergusson DM, Horwood LJ, Lynskey MT. Early dentine lead levels and subsequent cognitive and behavioural development. J Child Psychol Psychiatry 1993;34:215-27. DOI: https://doi.org/10.1111/j.1469-7610.1993.tb00980.x

16. Committee on Environmental hazards and Committee on Accident and Poison prevention statement on childhood lead poisoning. Paediatrics. 1987;79:457-65.

17. Järup L. Hazards of heavy metal contamination. British Medical Bulletin. 2003;68:167-82. https://doi.org/10.1093/ $\mathrm{bmb} / \operatorname{ldg} 032$

18. Wecker L, Miller SB, Cochran SR, Dugger DL, Johnson WD. Trace element concentrations in hair from autistic children. J Ment Defic Res. 1985;29:15-22. DOI: https://doi.org/10.1111/j.1365-2788.1985.tb00303.x

19. Kern JK, Grannemann BD, Trivedi MH, Adams JB. Sulfhydryl-reactive metals in autism. J Toxicol Environ Health A. 2007;70:715-21. DOI:10.1080/15287390601188060

20. Pandey PK, Yadav S, and Pandey M. Human Arsenic Poisoning Issues in Central-East Indian Locations: Biomarkers and Biochemical Monitoring Int. J. Environ. Res. Public Health 2007;4:15-22. DOI:10.3390/ijerph2007010003

21. Charney E, Kessler B, Farfel M, Jackson D. Childhood lead poisoning. A controlled trial of the effect of dustcontrol measures on blood lead levels. N Engl J Med. 1983;309:1089-9.

22. Kumar A, Scott Clark C. Lead loadings in household dust in Delhi, India. Indoor Air. 2009;19:414-20. DOI: 10.1111/j.1600-0668.2009.00605.x.

23. Kumar A, Gottesfeld P. Lead content in household paints in India. Sci Total Environ. 2008;407:333-7. DOI: 10.1016/j.scitotenv.2008.08.038.

24. Prasad AS. Zinc in human health: effect of zinc on immune cells. Mol. Med. 2008;14:353-7. DOI: 10.2119/2008-00033. 
25. Lakshmi P, Geetha A. Level of trace elements (copper, zinc, magnesium and selenium) and toxic elements (lead and mercury) in the hair and nail of children with autism. Biol Trace Elem Res. 2011;142:148-58. DOI: 10.1007/ s12011-010-8766-2.

26. Mohamed Fel B, Zaky EA, El-Sayed AB, Elhossieny RM, Zahra SS, Salah Eldin W, et al. Assessment of Hair Aluminum, Lead, and Mercury in a Sample of Autistic Egyptian Children: Environmental Risk Factors of Heavy Metals in Autism. Behav Neurol. 2015;2015:545-674. DOI: 10.1155/2015/545674. 